\title{
MODELLING THE TRANSPORTATION EFFICIENCY OF AN EDUCATIONAL INSTITUTE
}

\author{
ADEDUGBA Adebayo T. ${ }^{1}$, OGUNNAIKE Olaleke $0 .{ }^{2}$, ADEYEMO Kingsley $\mathrm{A}^{3}$ \& \\ KEHINDE Busola E. ${ }^{4}$ \\ ${ }^{1}$ Department of Business Management, Covenant University, Ogun State, Nigeria, \\ adebayo.adedugbapgs@stu.cu.edu.ng \\ ${ }^{2}$ Department of Business Management, Covenant University, Ogun State, Nigeria, \\ olaleke.ogunnaike@covenantuniversity.edu.ng \\ ${ }^{3}$ Department of Accounting, Covenant University, Ogun State, Nigeria, \\ kingsley.adeyemo@covenantuniversity.edu.ng \\ ${ }^{4}$ Department of Business Management, Covenant University, Ogun State, Nigeria, \\ busola.kehinde@covenantuniversity.edu.ng
}

\begin{abstract}
The study utilized a model of linear transportation to locate the base expense of moving educational materials from the educational institute (distribution centres) to the branches (request or demand area). The information was analysed using QM software 2013. Consequently, the examination shows that the Northwest corner technique was $\$ 292,750000$, the minimum cost technique was $\$ 273,500000$ and Vogel's estimation technique was $\$ 230,000000$. Based on the outcome Vogel's estimation technique was a proficient technique due to lower cost. The modified distribution method (MODI) was utilized to optimize the techniques to arrive at a final feasible output of $\$ 230,000,000$. The transportation model will enable the organization to distribute educational materials optimally at a transportation cost of $\$ 230,000000$ via an optimal route.
\end{abstract}

Keywords: Modified distribution method (MODI), Vogel estimation technique, Northwest corner technique, Minimum cost technique.

\section{INTRODUCTION}

The transportation of goods comes to play at a cost that does not add any incentive in terms of size, amount, or quality to the product. However, it guarantees the delivery and sale of goods. This expense is borne by either the organization or the client through the increment of transportation cost or the cost of the goods respectively. The cost of transportation varies with the method adopted by the organization and the specific method picked is subject to the qualities of the method and the organization's specifications. In Nigeria, road transportation is the predominant method of movement as it represents about $90 \%$ of the inner movement of travellers and cargoes (Edokpia \& Amiolemben, 2016). Transportation problem model basically minimizes the 
expense of shipping an item from different sources $(m)$ to the desired locations $(n)$. Transportation problem model aims at moving various measures of homogeneous things that are kept at different locations to various demand sites at an absolute transportation cost that is minimal (Ibidunni, Ufua, Okorie, \& Kehinde, 2019; Aliyu, Usman, Babayaro, \& Aminu, 2019).

According to Juman and Nawarathne (2019), there are three fundamental procedures to obtain an underlying basic solution in transportation problem model they are Northwest corner method, the minimum cost technique, and Vogel's estimation technique. Meanwhile, the key procedures acquire a near optimal solution is the stepping stone strategy and modified distribution technique (Ogunnaike, Bishop, Akinsulire, Kehinde, \& Oreagba 2018; Adebayo, Kehinde, Ogunnaike, Olaoye, \& Adesanya, 2019). The study utilized Vogel's estimation technique, the least cost technique, Northwest corner method, and the modified distribution approach, to optimize the transportation cost and determine the optimal course.

\section{LITERATURE REVIEW}

Radthy, Maghool, and Khaleel (2019) applied the base cell cost strategy and Vogel estimation technique in a domestic food company. The initial solution obtained is evaluated utilizing the stepping stone test so as to get the ideal solution. A significant aspect of linear programming is transportation model however; a methodology was engaged by Ghadle and Munot (2019) to improve the current solution with advances using a fuzzy transportation model. An inventive hypothesis was discussed by Sumathi and Bama (2019) to attain an optimal cost in transportation using Vogel's estimation technique and the modified distribution method (MODI) Singh, Pradhan, and Biswal (2019) stated that a three-dimensional transportation issue is an unstable multi-objective dynamics (MODM) issue. Specifically, it includes scanning for the best transportation set-up that meets the management inclinations by considering the clashing goals/measures. The study proposed a general definition of the multi-objective transportation issue with some irregular boundaries using fuzzy transportation problem model. A straightforward methodology was proposed to obtain the best answer for the linear multi-objective transportation issues. A proficient feasible output was obtained by the proposed approach additionally, this methodology is easy to utilize and less tedious (Kaur, Rakshit, \& Singh, 2018).

A reasonable goal for appropriating the items in the chosen area has been picked cautiously based on the request and least rent of the distribution centres. Banik and Hasan, (2018) formulated a mathematical transportation model and the iteration was carried using ' $C$ ' programming language utilizing Vogel's technique. The feasible solution indicated that the optimal measure of supply with the relating location in demand.

\section{JUSTIFICATION FOR THE STUDY}

An educational institute in Lagos intends to move educational materials such as textbooks to its various branches within the metropolis. However, the advent of covid 19 has caused a major disruption in transportation. As a result the cost of transportation is high. In other to overcome this bottleneck the determination of an optimal transportation course is very important. While, the minimization of transportation cost to augment profitability is key. In this manner, there is a need to obtain an appropriate mechanism for conveying educational materials at a limited transportation cost to the chosen location based on request and supply. Therefore, the study mathematically investigates and provided ways to minimize transportation cost and select an optimal route.

\section{OBJECTIVE OF THE STUDY}

The objective of the study is to minimize transportation cost and determine an optimal route utilizing transportation problem model such as Vogel's estimation technique, minimum cost technique, Northwest corner method and modified distribution (MODI) algorithm.

\section{METHODOLOGY}

$$
\begin{gathered}
\text { Minimize } \mathrm{z}=\sum_{i=1}^{m} \sum_{j=1}^{n} C i j X i j \ldots \ldots \ldots \ldots \ldots \ldots \ldots . . . . . . \ldots j e c t i v e \text { Function } \\
\sum_{j=1}^{n} X i \leq \mathrm{a}_{\mathrm{i}}, \mathrm{i}=1,2,3 \ldots \ldots \mathrm{m} \quad \text { (Request) } \\
\sum_{j=1}^{n} X i_{j} \geq \mathrm{b}_{\mathrm{j}}, \mathrm{j}=1,2,3 \ldots \ldots \mathrm{n} \quad \text { (Supply) } \\
\mathrm{X}_{\mathrm{ij}} \geq 0(\mathrm{i}=1,2,3 \ldots \mathrm{m}, \mathrm{j}=1,2,3 \ldots \ldots \mathrm{n})
\end{gathered}
$$


$\mathrm{m}=$ sources, $\mathrm{n}=$ locations in the objective function, $\mathrm{a}=$ volume of the ith sources, $\mathrm{bj}=$ request of jth request locations, $\mathrm{Cij}=$ cost of material delivery (dispatching cost) between ith origin and jth request locations, $\mathrm{Xij}=$ measure of material sent from ith source to jth request locations. The minimum cost technique, Northwest corner method, Vogel's estimation technique and, the modified distribution (MODI) was engaged to obtain a feasible solution. This will be done via QM software.

\section{DATA ANALYSIS AND PRESENTATION}

The information for this research was a secondary data gathered from the educational institute. The information includes the transportation cost, requests from the branches and supplies from the organization. The information was investigated using minimum cost technique, Northwest corner technique, Vogel's approximation technique and the modified distribution method (MODI) via QM software. An underlying feasible solution cannot be considered optimal, in light of the fact that there may exist another solution. To examine if an answer is the basic feasible solution for a specific issue, an optimality test was engaged. The study utilized optimality test for all the underlying feasible solution gotten from different technique engaged in the study. This was done to determine the optimality for each technique.

The modified distribution (MODI) was utilized to test for optimality. The table 1 underneath shows the standard transportation cost of moving items from the educational institute (supply) to the different request or demand locations (branches). The transportation cost for each cell is in Naira and it is represented in thousand. While, the supply represents the quantity available at the educational institute and the demand represents the request from the client. In transportation problem model it is fundamental to determine state of the model if it is balanced or not.

i. If total request or demand = total supplies, this implies the model is balanced.

ii. If total request or demand $\neq$ total supplies, this implies the model is not balanced.

From Table 1, the overall request or demand $=20,000$ and the overall supply $=40,000$. This is an unequal model. Therefore, there is a need to balance the model by introducing a dummy request or demand. The dummy request or demand was obtained by subtracting the total request or demand from the total supply i.e. $40000-20000=20000$ from table 1 . Table 2 beneath shows the balanced transportation problem model therefore the initial basic feasible solution was obtained.

Table 1: Information sourced from the educational institute

\begin{tabular}{|l|l|l|l|l|l|}
\hline $\begin{array}{l}\text { Demand } \\
\text { Supplies }\end{array}$ & Idumota & $\begin{array}{l}\text { Iyana } \\
\text { Ipaja }\end{array}$ & Ikeja & Agege & Supply \\
\hline Ilupeju & 20 & 17 & 8 & 15 & 10000 \\
\hline Isolo/Mushin & 15 & 8 & 20 & 8 & 20000 \\
\hline Asawani & 27 & 15 & 8 & 20 & 10000 \\
\hline Demand & 10000 & 2500 & 6375 & 1125 & \\
\hline
\end{tabular}

Table 2: Balanced transportation tableau

\begin{tabular}{|l|l|l|l|l|l|l|}
\hline $\begin{array}{l}\text { Demand } \\
\text { Supplies }\end{array}$ & Idumota & $\begin{array}{l}\text { lyana } \\
\text { Ipaja }\end{array}$ & Ikeja & Agege & Dummy & Supply \\
\hline Ilupeju & 20 & 17 & 8 & 15 & 0 & 10000 \\
\hline Isolo/Mushin & 15 & 8 & 20 & 8 & 0 & 20000 \\
\hline Asawani & 27 & 15 & 8 & 20 & 0 & 10000 \\
\hline Demand & 10000 & 2500 & 6375 & 1125 & 20000 & 40000 \\
\hline
\end{tabular}


Proceedings of INTCESS 2021 8th International Conference on Education and Education of Social Sciences

Table 3: Minimum cost technique underlying feasible solution

\begin{tabular}{|c|c|c|c|c|c|}
\hline & Idumota & $\begin{array}{c}\text { Iyana } \\
\text { Ipaja }\end{array}$ & Ikeja & Agege & Dummy \\
\hline Ilupeju & $(5)$ & $(9)$ & $(12)$ & $(7)$ & $\begin{array}{c}(0) \\
10000\end{array}$ \\
\hline Isolo/Mushin & $\begin{array}{c}(15) \\
6375\end{array}$ & $\begin{array}{c}(8) \\
2500\end{array}$ & $(24)$ & $\begin{array}{c}(8) \\
1125\end{array}$ & $\begin{array}{c}(0) \\
10000\end{array}$ \\
\hline Asawani & $\begin{array}{c}(27) \\
3625\end{array}$ & $(-5)$ & $\begin{array}{c}(8) \\
6375\end{array}$ & $(0)$ & $(-12)$ \\
\hline
\end{tabular}

$\operatorname{Min} Z=15^{\star} 6375+8^{\star} 2500+1125^{\star} 8+3625^{\star} 27+6375^{\star} 8+10000^{\star} 0+10000^{*} 0=273500$.

Table 4: Testing for optimality using modified distribution (MODI)

\begin{tabular}{|c|c|c|c|c|c|}
\hline & Idumota & $\begin{array}{l}\text { Iyana } \\
\text { Ipaja }\end{array}$ & Ikeja & Agege & Dummy \\
\hline Ilupeju & $(5)$ & $(9)$ & $(0)$ & $(7)$ & $\begin{array}{c}(0) \\
10000\end{array}$ \\
\hline Isolo/Mushin & $(15)$ & $(8)$ & $(12)$ & $(8)$ & $(0)$ \\
& 10000 & 2500 & & 1125 & 6375 \\
\hline Asawani & $(12)$ & $(7)$ & $(8)$ & $(12)$ & $(0)$ \\
& & & 6375 & & 3625 \\
\hline
\end{tabular}

$\operatorname{Min} Z=10000^{\star} 15+2500^{\star} 8+6375^{\star} 8+1125^{\star} 8+10000^{\star} 0+6375^{\star} 0=23000$

Table 5: Northwest corner technique iteration 1

\begin{tabular}{|c|c|c|c|c|c|}
\hline & Idumota & Iyana Ipaja & Ikeja & Agege & Dummy \\
\hline Ilupeju & 10000 & $(4)$ & $(-17)$ & $(2)$ & $(-5)$ \\
\hline Isolo/Mushin & $(0)$ & 2500 & 6375 & 1125 & $(0) 10000$ \\
\hline Asawani & $(12)$ & $(7)$ & $(-12)$ & $(12)$ & $(0) 10000$ \\
\hline
\end{tabular}

Table 6: Northwest cost technique underlying feasible solution

\begin{tabular}{|c|c|c|c|c|c|}
\hline & Idumota & $\begin{array}{l}\text { Iyana } \\
\text { Ipaja }\end{array}$ & Ikeja & Agege & Dummy \\
\hline Ilupeju & $\begin{array}{c}(20) \\
3625\end{array}$ & (4) & $\begin{array}{c}(15) \\
6375\end{array}$ & (2) & $(-5)$ \\
\hline Isolo/Mushin & $\begin{array}{c}(15) \\
6375\end{array}$ & $\begin{array}{c}(8) \\
2500\end{array}$ & (17) & $\begin{array}{c}(8) \\
1125\end{array}$ & $\begin{array}{c}(0) \\
10000\end{array}$ \\
\hline Asawani & (12) & (7) & (5) & (12) & $\begin{array}{c}(0) \\
10000\end{array}$ \\
\hline
\end{tabular}

$\operatorname{Min} Z=3625^{\star} 20+6375^{\star} 15+1125^{\star} 8+2500^{\star} 8+6375^{\star} 15+10000^{\star} 0+10000^{\star} 0=292750$. 
Table 7: Testing for optimality using modified distribution(MODI)

\begin{tabular}{|c|c|c|c|c|c|}
\hline & Idumota & $\begin{array}{c}\text { Iyana } \\
\text { Ipaja }\end{array}$ & Ikeja & Agege & Dummy \\
\hline Ilupeju & $(5)$ & $(9)$ & $\begin{array}{c}(8) \\
6375\end{array}$ & $(7)$ & $\begin{array}{c}(0) \\
3625\end{array}$ \\
\hline Isolo/Mushin & $(15)$ & $(8)$ & $(12)$ & $(8)$ & $(0)$ \\
& 10000 & 2500 & & 1125 & 6375 \\
\hline Asawani & $(12)$ & $(7)$ & $(0)$ & $(12)$ & $(0)$ \\
& & & & & 10000 \\
\hline
\end{tabular}

$\operatorname{Min} Z=10000^{\star} 15+2500^{\star} 8+6375^{\star} 8+1125^{\star} 8+3625^{\star} 0+6375^{\star} 0+10000^{\star} 0=230000$

Table 8: Vogel estimation final feasible solution using modified distribution (MODI)

\begin{tabular}{|c|c|c|c|c|c|}
\hline & Idumota & $\begin{array}{l}\text { Iyana } \\
\text { Ipaja }\end{array}$ & Ikeja & Agege & Dummy \\
\hline Ilupeju & (5) & (9) & (0) & (7) & $\begin{array}{c}(0) \\
10000\end{array}$ \\
\hline Isolo/Mushin & $\begin{array}{c}(15) \\
10000\end{array}$ & $\begin{array}{c}(8) \\
2500\end{array}$ & (12) & $\begin{array}{c}(8) \\
1125\end{array}$ & $\begin{array}{c}(0) \\
6375\end{array}$ \\
\hline Asawani & $(12)$ & (7) & $\begin{array}{c}(8) \\
6375\end{array}$ & (12) & $\begin{array}{c}(0) \\
3625\end{array}$ \\
\hline
\end{tabular}

$\operatorname{Min} Z=10000^{\star} 15+2500^{\star} 8+1125^{\star} 8+6375^{\star} 0+6375^{\star} 8+3625^{\star} 0=23000$

The underlying feasible solution and final solution utilizing the minimum cost technique, Northwest technique, Vogel's estimation technique and the modified distribution(MODI) respectively are stated below, however transportation cost for each cell is in Naira and it is represented in thousand.

$>$ Minimum cost technique underlying feasible solution is : 273500

A273500* $1000=\$ 273,500000$.

$>$ Northwest technique underlying feasible solution is: 292750

\#292,750*1000 = $\$ 292,750000$.

$>$ Vogel's estimation technique underlying feasible solution is: $\$ 230,000$

\#2300,00*1000 $=$ 230,000 000 .

The above outcome portrays that Vogel estimation technique is the most effective considering the number of iterations. It has the least transportation cost before optimality test and require less cycle time. The Northwest corner, Minimum cost and Vogel estimation technique gave an equivalent output of $\$ 23,000,000$ after utilizing the modified distribution (MODI). This shows, the three techniques can be utilized to decide the solution to a given linear transportation model. 


\section{CONCLUSION}

The technique of Northwest corner, minimum cost and Vogel estimation furnished different outputs. The Northwest corner technique was $\$ 292,750$ 000, minimum cost technique was $\$ 273,500000$ and Vogel estimation was 230,000000 as the cost of transportation. The outcome shows that Vogel estimation technique is more proficient than other techniques. After the application of MODI (the modified distribution) the three techniques produced similar output of $\$ 230,000,000$. This shows that, all the three techniques can be utilized to decide the solution to a given linear transportation model. Table 8 shows that, 10,000 packs of textbooks is allocated from Isolo/mushin to Idumota, 2500 packs of textbooks to lyana Ipaja, 1125 packs of textbooks to Agege and, 6375 packs of textbooks from Asawani to Ikeja. Based on the model an optimal distribution of educational materials was attained to serve different demand locations from Idumota to Iyana-Ipaja to Agege and Ikeja. The optimization of educational material distribution will help the organization to attain a transportation cost of $\$ 230,000000$.

\section{ACKNOWLEDGEMENT}

The authors acknowledge the erudite advice from the Department of Business Management at Covenant University who provided critical analysis to improve the study. We also thank all supporting individuals who contributed to this research.

\section{REFERENCE LIST}

Adebayo, O.P., Kehinde, O.J., Ogunnaike, O. O., , Olaoye, O.P. \& Adesanya, O.D. (2019). Educaion for sale: corporate brand identity and service quality in higher education Management. Polish Journal Of Management Studies, 20 (2): 45-59

Aminu.M.K., Babayaro..Z., Usman.U. and Aliyu.M.I (2019).A minimization of the cost transportation, American Journal of Operations Research, 9(1), 1-7.

Amiolemhen.P.E., and Edokpia.R.O (2016). Transportation cost minimization of a manufacturing firm using Genetic algorithm approach, Nigerian Journal of Technology, 35(4), 866-873.

Bama.S.V., and Sumath.P. (2019).An innovative route to acquire least cost in transportation problems, International Journal of Engineering and Advances Technology, 9(1), 5368-5369.

Banik.D., and Hasan.Z.M. (2018). Transportation cost optimization of an online business applying Vogel's method, International Scientific Journal, 96, 179-198.

Ghadle.P.K., and Munot.A.D (2019).Recent advances on reliable methods for solving transportation problem and fuzzy transportation problem, Asian Journal of Mathematics and Computer Research, 25(2), 95-107.

Ibidunni, A. S., Ufua, D. E., Okorie, U. E., \& Kehinde, B. E. (2019). Labour productivity in agricultural sector of Sub-Sahara Africa (2010-2017): A data envelopment and panel regression approach. African Journal of

Economic and Management Studies, 11(2), 207-232.

Juman.M.S and Nawarathne.A.S. (2019).An efficient alternative approach to solve a transportation problem, Ceylon Journal of Science, 48(1), 19-29.

Kaur.L., Rakshit.M., and Singh.S. (2018). A new approach to solve multi- objective transportation problem, International Journal of Application and Applied Mathematics, 13(1), 100-109.

Ogunnaike, O. O., Bishop, S. A., Akinsulire, H., Kehinde, B. E., \& Oreagba, O. T. (2018). Education for sale: Markov chain analysis of physical qualities and engineering students switching behaviour. International Journal of Mechanical Engineering and Technology, 9(12), 230-239.

Radthy.H.Z., Maghool.H.F. and Khaleel.H.A.(2019). Application of linear programming according to transportation problem on real data, International Journal of Scientific and Technology, 8(1), 100-102.

Singh.S., Pradhan.A., and Biswal.M.P (2019). Multi-objective solid transportation problem under stochastic environment, Indian Academy of Science, 44, 1-12. 